\title{
Pollen and plant macrofossil analyses of radiocarbon dated mid-Holocene profiles from two subalpine lakes in the Rila Mountains, Bulgaria
}

\author{
Spassimir Tonkov* and Elena Marinova
}

\author{
(Laboratory of Palynology, Department of Botany, Faculty of Biology, Sofia \\ University St. Kliment Ohridski, 8 Dragan Tsankov bd., Sofia 1164, Bulgaria)
}

Received 10 March 2004; revised manuscript accepted 22 September 2004

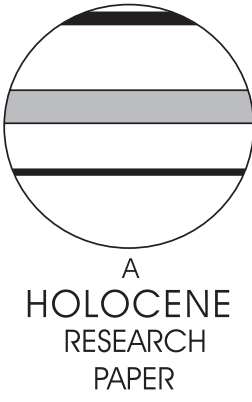

\section{Introduction}

The development of mountain ecosystems in the temperate regions after the end of the last glaciation is a reflection of dynamic processes related mainly to climate changes, reforestation and human impact. Studies of past environmental change in mountains are extremely important and valuable in this context, owing to the inherent climatic sensitivity of mountain ecosystems (Reasoner et al., 2001). On a continental scale the general picture of this development during the Holocene appears rather diverse for southeastern Europe and the Balkan peninsula in particular, bearing in mind its complex topography, the interaction of several climatic influences, the rich flora and vegetation and, not least, the millennial anthropogenic influence (Lang, 1994; Willis, 1994).

*Author for correspondence: (e-mail: tonkov@biofac.uni-sofia.bg)
Mountain lakes are amongst the most suitable sites for palaeoecological reconstructions in an attempt to decipher historical records because their sediments often contain a sufficient quantity of well-preserved plant fossils considered as valuable proxies of past environmental changes. For studies tracing the fluctuations in the sensitive ecotone zone between the forest and the subalpine area it seems desirable to combine pollen analysis with plant macrofossil determination in order to obtain more reliabale information about the environmental situation at that particular altitude (Lang and Tobolski, 1985).

The key geographical position of Bulgaria in the middle of the Balkan peninsula provides excellent opportunities for understanding the complex mechanisms of vegetation development in postglacial time in this part of southeastern Europe by investigation of high-altitude lakes that are sensitive enough to archive environmental changes. Until recently, the palaeoecological evidence obtained from lake sediments in the Rila Mountains (2925 m), the highest massif on the peninsula, was 
derived from palynological studies supplemented with radiocarbon dates (Tonkov et al., 1998; Bozilova and Tonkov, 2000). The only exceptions so far, which combine pollen and plant macrofossil analyses, are the investigations of sediments from the peat bog Suho Ezero (1900 m), a former lake in the South Rila Mountains (Bozilova et al., 1990), and from Lake Panichishte $(1345 \mathrm{~m})$ in the Northwestern Rila Mountains (Bozilova et al., 2002; Marinova and Tonkov, 2003). The first of these sites spans part of the Lateglacial and the entire Holocene with a detailed radiocarbon chronology for the last 3000 years, while the second site dates back to historical times.

This paper presents the results from the palaeoecological study of the sediments of two subalpine lakes, undertaken as a part of the Mountain Research Initiative (MRI) in collaboration with Past Global Changes (PAGES), aiming to obtain through a multidisciplinary approach new information on the Holocene vegetation dynamics and climate change at high altitudes in the Central Rila Mountains, an area that has not been sufficiently investigated. Moreover, this palaeovegetational reconstruction throws additional light on the dynamic Holocene forest development in the high mountains on the peninsula in evaluating more precisely the role of ecological, climatological and anthropogenic factors.

\section{Study area}

\section{Geography, geology, climate and modern vegetation}

The Rila Mountains range is situated in Southwestern Bulgaria (lat. $41^{\circ} 52^{\prime} 30^{\prime \prime}-42^{\circ} 21^{\prime} 40^{\prime \prime} \mathrm{N}$, long. $23^{\circ} 01^{\prime} 22^{\prime \prime}-24^{\circ} 01^{\prime \prime} \mathrm{E}$ ), surrounded by the basins of three main rivers that divide it into four parts (Figure 1). The mountain is geologically complex, being composed of Palaeozoic metamorphic rocks (crystalline schist and marble) and intrusive rocks (granite). Plentiful geomorphological evidence is available for the last two glaciations, when the activity of the mountain glaciers led to the formation of typical glacial relief forms with cirques, numerous lakes (approximately 140), moraines and trough river beds. It was suggested that the valley glaciers stretched down to approximately 1300 m (Glovnja, 1968; Velchev, 1995). The exact timing of the start of deglaciation is still unknown but the most recent palynological evidence suggests that the accumulation of sediments in the glacial lakes began earlier than 13000 yr BP (Bozilova and Tonkov, 2000).

The climate below $1000 \mathrm{~m}$ is transitional between continental and submediterranean. Above $1000 \mathrm{~m}$ the microclimate becomes montane and the mean temperature drops by $0.5^{\circ} \mathrm{C}$ with each $100-\mathrm{m}$ increase in altitude. The mean annual precipitation is $800-1000 \mathrm{~mm}$, much of it snow at higher altitudes (Tishkov, 1976).

The present vegetation of the Rila Mountains has six vegetation altitudinal belts (Velchev and Tonkov, 1986; Bondev, 1991). A comprehensive description of the structure and composition of these vegetation belts in the Central Rila Mountains has been presented in earlier publications (Tonkov et al., 1998, 2000).

It is worth noting that above the xerothermic and xeromesophilous oak and hornbeam belts (up to $1000 \mathrm{~m}$ ) dominated by Quercus cerris, $Q$. pubescens, $Q$. frainetto, $Q$. dalechampii, Carpinus orientalis, Carpinus betulus with an admixture of Ulmus glabra, Acer platanoides and Acer pseudoplatanus, fragments of beech forests (Fagus sylvatica) are found. Beech also forms mixed woodstands with Abies alba and Picea abies at altitudes of $1400-1600 \mathrm{~m}$. The coniferous belt (1600-2000 $(2200 \mathrm{~m}))$ is the most compact and well-developed vegetation belt, and is composed mainly of forests of Pinus sylvestris and
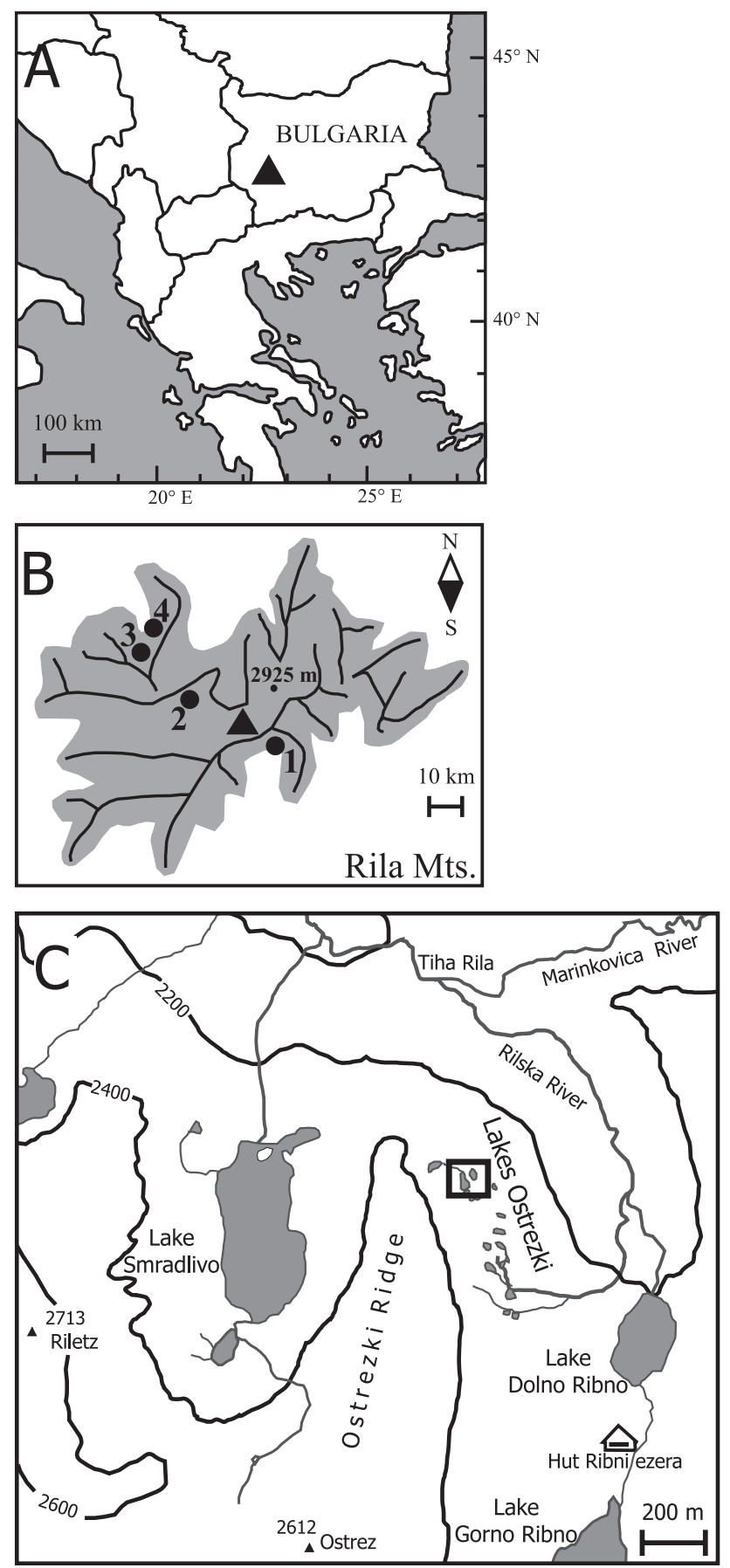

Figure 1 A. Location of Rila Mountains (solid triangle) on the Balkan peninsula. Scale bar, $100 \mathrm{~km}$. B. Morphographic map of Rila Mountains and the location of sites (solid circles) mentioned in text: 1, peat bog Suho Ezero (Bozilova and Smit, 1979; Bozilova et al., 1990; Bozilova, 1995); 2, Lake Suho Ezero (Tonkov et al., 1998); 3, Lake Sedmo Rilsko (Bozilova and Tonkov, 2000); 4, Lake Panichishte (Bozilova et al., 2002; Marinova and Tonkov, 2003); solid triangle, the study area of Lakes Ostrezki. Scale bar, $10 \mathrm{~km}$. C. Central Rila Mountains showing the group of Lakes Ostrezki (open rectangle). Scale bar, $200 \mathrm{~m}$

Picea abies. The Balkan endemic Pinus peuce forms a sub-belt and shapes the treeline in the western and southern parts of the mountain. Within this zone communities of Abies alba, Betula pendula, Populus tremula and Juniperus sibirica also occur.

The subalpine belt $(2200-2500 \mathrm{~m})$ on northern slopes, particularly in the central and eastern parts, is dominated by thick impenetrable formations of Pinus mugo (dwarf-pine) with $J$ sibirica, Vaccinium myrtillus and herbaceous communities on 
open areas. Alnus viridis is mainly restricted to mountain brooks along the steep, rocky slopes. The alpine belt (2500$2925 \mathrm{~m}$ ) is dominated by the herbaceous communities of Carex curvula, Festuca airoides, F. riloensis, Dryas octopetala, Salix herbaceae, etc.

Today the vegetation in almost all belts is influenced by anthropogenic activity and, in many places, the treeline has been artificially lowered.

\section{Sites of investigation}

The group of Ostrezki Lakes $\left(42^{\circ} 08^{\prime} \mathrm{N}, 23^{\circ} 28^{\prime} \mathrm{E}\right)$ on the Central Rila Mountains comprises several lakes with a permanent water surface and half a dozen smaller ones that dry up during summer. The group is located in the subalpine belt above the present treeline on the western slope of a large cirque (Figure 1C). Lake Ostrezko-2 $(2320 \mathrm{~m})$ has an elliptic shape with peaty shores and an area of about $1.5 \mathrm{dka}$ (Figure 2). The water depth is $1.5 \mathrm{~m}$. Lake Ostrezko-3 (2340 m) has a circular shape with an area of about $1.0 \mathrm{dka}$ and water depth of $1.7 \mathrm{~m}$. The distance between the lakes is $150 \mathrm{~m}$. Today the lakes are surrounded by groups of Pinus mugo, J. sibirica and herb vegetation composed of Nardus stricta, Poa alpina, Deschampsia caespitosa, Carex nigra, Carex echinata, Campanula alpina, Geum coccineum, Geum montanum, Ranunculus montanus, Potentilla ternata, Dianthus microlepis, Plantago gentianoides, Primula deorum, Gentiana pyrenaica, etc.

\section{Materials and methods}

\section{Coring and lithology}

The material for analyses from Lake Ostrezko-2 was obtained from the northern peaty shore. The core length was $200 \mathrm{~cm}$. The material consists of lake mud overlain in the uppermost $25 \mathrm{~cm}$ by undecomposed Sphagnum peat. The second coring was done in the southern periphery of Lake Ostrezko-3 at water depth of $70 \mathrm{~cm}$. The core retrieved was $180 \mathrm{~cm}$ long. The sediment consists of lake mud. The equipment used was a Dachnowski hand-operated corer.

\section{Pollen analysis}

Both cores were sampled at $5-10 \mathrm{~cm}$ intervals, and a volume of $2 \mathrm{~cm}^{3}$ for each sample was treated with $\mathrm{HF}$ acid with subsequent acetolysis (Faegri and Iversen, 1989). The pollen sum (PS) used for percentage calculations is based on total terrestrial pollen $(\mathrm{AP}+\mathrm{NAP})$. In most instances a PS of $500-$ 600 was achieved. Spores of mosses and pteridophytes, and pollen of aquatics and Cyperaceae were excluded from the PS. Their representation is expressed as percentages of the PS as defined above. Taxa with low frequencies or of less importance are not shown in the pollen diagrams (Figures 3 and 4). The identification of spores and pollen was made using the reference collection of the Laboratory of Palynology and the keys in Beug (1961), Faegri and Iversen (1989) and Moore et al. (1991). For calculation and drawing of the pollen diagrams the programs TILIA and TILIA*GRAPH were used (Grimm, 1991). The subdivision of the pollen diagrams into Local Pollen Assemblage Zones (LPAZ) and their subsequent correlation was performed by the application of CONISS (Grimm, 1987). The zones are numbered from the base upward and prefixed by the site designation OSTR.

\section{Plant macrofossil analysis}

The samples for plant macrofossil analysis were taken every 10 or $20 \mathrm{~cm}$. After soaking in $\mathrm{KOH}$ the material was sieved in two fractions through meshes of 0.4 and $0.16 \mathrm{~mm}$. The plant remains were studied at magnification $10-40 \times$. Sections from wood fragments larger than $0.5 \mathrm{~cm}$, were analysed under light microscope. The identification was performed using the reference collection kept in the Herbarium of Sofia University (SO) and several literature sources (Beijerinck, 1947; Katz et al., 1977; Schoch et al., 1988; Schweingruber, 1990; Tobolski, 2000). Cuticular analysis was also applied in an attempt to distinguish between the needles originating from Pinus mugo and Pinus sylvestris (Struzkova, 2002). The results are graphically plotted as two diagrams (Figures 5 and 6) using TILIA and TILIA*GRAPH programs (Grimm, 1991). Macrofossils such as fruits and seeds are presented in absolute numbers per $20 \mathrm{ml}$ (Lake Ostrezko-2) and per $40 \mathrm{ml}$ (Lake Ostrezko-3). The abundance of wood fragments and remains of vegetative parts (stems, leaves, etc.) is shown on a relative scale by black dots.

\section{Radiocarbon dating}

Five ${ }^{14} \mathrm{C}$ dates were determined on bulk peat and lake mud samples in the Radiocarbon Laboratory at the University of Bern, Switzerland (Lake Ostrezko-2) and in the Radiocarbon AMS Laboratory at Max-Plank Institute for Biogeochemistry,

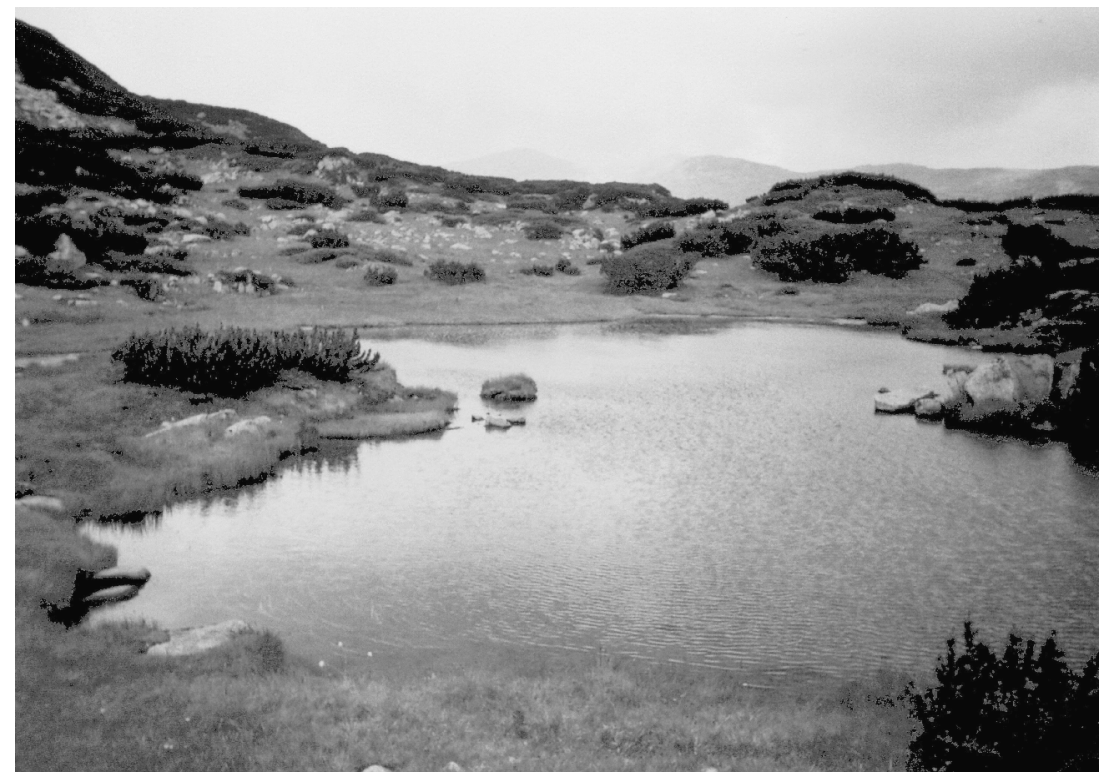

Figure 2 A view of Lake Ostrezko-2 


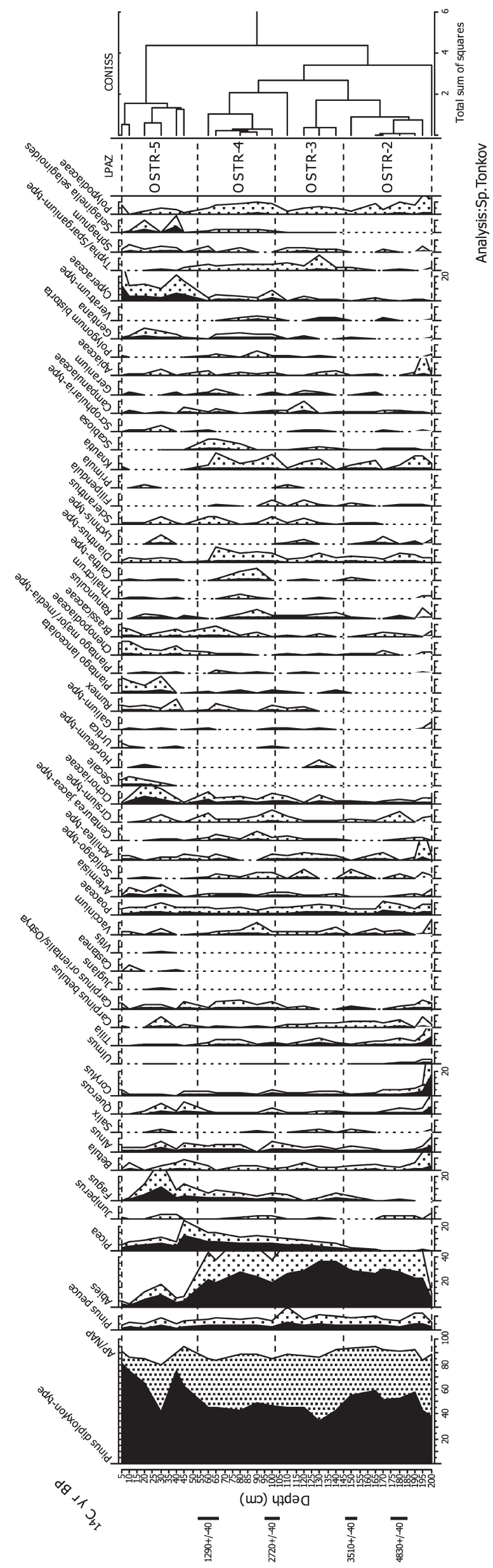

Figure 3 Percentage pollen diagram from the core Lake Ostrezko-2
Jena, Germany (Lake Ostrezko-3). The dates have been calibrated to calendar years with the computer program OxCal v3.5 (Bronk Ramsey, 2000). The results are shown in Table 1. The dates in the discussion are given as calibrated radiocarbon years BP (cal. BP) unless otherwise stated.

\section{Results}

\section{Radiocarbon chronology}

The radiocarbon measurements indicated that the bottom part of the sequence from Lake Ostrezko-3 was older than 5700 BP (6500 cal. BP). A depth-age model constructed by linear interpolation for the sequence from Lake Ostrezko-2 shows an age of c. 6000 cal. BP (Figure 7). This model also implies somewhat faster rates of sedimentation for the time intervals $3770-2800 \mathrm{cal}$. BP and from $1240 \mathrm{cal}$. BP to the present. Important changes in the pollen stratigraphy of both cores are clearly identified and tied to the corresponding radiocarbon age.

\section{Pollen stratigraphy}

The palynostratigraphical correlation of the sequences analysed is feasible because of the presence of reliable markers, i.e., similarities in the behaviour of the main pollen curves, the delimitation of LPAZ by CONISS and the application of the depth-age model constructed by linear interpolation. As a result five LPAZ (OSTR-1 ... OSTR-5) are recognized and their description is summarized in Table 2. The oldest LAPZ OSTR-1 $(180-115 \mathrm{~cm})$ is present only in the pollen diagram from Lake Ostrezko-3 (Figure 4).

\section{Plant macrofossils}

The analysis was focused on the core from Lake Ostrezko-2 (Figure 5) which is bound to a radiocarbon chronology. Regarding the core from Lake Ostrezko-3 (Figure 6), the main interest was concentrated on the lowermost part (180$115 \mathrm{~cm}$ ) that corresponds to the oldest LPAZ OSTR -1 . The results from the macrofossil determination allow three Local Macrofossil Assemblage Zones (LMAS) to be distinguished and their description is summarized in Table 3.

\section{Discussion}

The palaeoecological record derived from pollen and plant macrofossil analyses of the sediments studied extends back to c. 6500-6700 cal. BP, i.e., the mid-Atlantic. This is a characteristic benchmark of the Holocene vegetation dynamics in the high central area of the Balkan peninsula (Rila, Pirin and Rhodopes Mountains), when important changes in forest composition and altitudinal vegetation zonation began to take place (Bozilova, 1996). At that time mesophilous deciduous forests, dominated by Quercus with abundant Tilia, Ulmus and Corylus, were distributed in the Central Rila Mountains at low altitudes (LPAZ OSTR-1, Quercetum mixtum-Corylus phase). The absence of a dense forest canopy above this vegetation belt, where pioneer forests of Betula with stands of Pinus were spread, has facilitated the air transport of deciduous tree pollen upslope to the subalpine zone. The end of this deciduous forest phase is determined at $c$. $6000 \mathrm{cal}$. BP (zone boundary OSTR-1/2), this age is in good conformity with previous investigations in the Rila Mountains (Bozilova et al., 1990; Bozilova and Tonkov, 2000). The decline in the percentage of Betula pollen marks the end of the vast spread of birch at mid and higher altitudes for nearly 4000 years after the onset of the Holocene (Bozilova, 1996). 


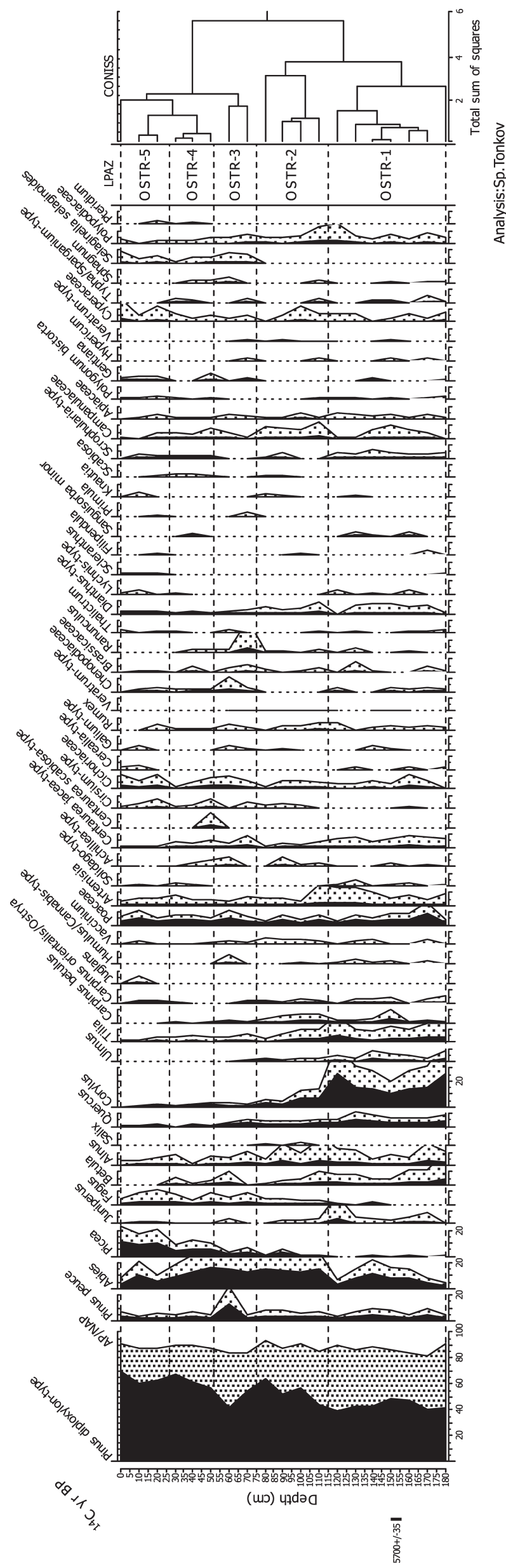

Figure 4 Percentage pollen diagram from the core Lake Ostrezko-3
The environmental conditions after $c .6700 \mathrm{cal}$. BP appeared to be extremely favourable for the vertical immigration of the conifers, particularly for Abies alba from the lower slopes and for Pinus peuce. The spread of the conifers was probably facilitated by an increase in humidity and precipitation, and following the establishment of soils with humic horizons (Bennett and Willis, 1995). Recent reconstructions of the climate for the millennium around $6000 \mathrm{BP}$ indicate a change towards cooler summers and warmer winters in southeastern Europe and the northern Mediterranean region (Cheddadi et al., 1997) in contrast to a mid-Holocene warming in northern Europe (Davis et al., 2003).

The macrofossil finds (zone MacroOstr-1) as well as the pollen data point to the existence of stands of Pinus mugo and Juniperus sibirica, and of Alnus viridis along mountain brooks, at that altitude among patches of herb vegetation composed of various species of Poaceae, Brassicaceae, Dianthus, Silene, Thymus, Potentilla, etc. The treeline shaped by Pinus sylvestris and Pinus peuce was in close proximity to the lakes. Convincing evidence for this are the cones and needles of Pinus peuce and Pinus sylvestris found in the sediments (Figure 5) which unlike pollen can not be transported from relatively long distance. The macroremains of Pinus peuce also indicate that this Balkan endemic was found at greater elevations than in modern times. In comparison, the counterpart section from the peat bog Suho Ezero $(1900 \mathrm{~m})$ in the South Rila Mountains (Bozilova et al., 1990) related to the mid-Holocene and dated at $5680 \pm 75 \mathrm{BP}$, also contains even higher pollen values $(10 \%)$ and abundance of needles of Pinus peuce. Undoubtedly, by that time the position of the treeline in some areas was reaching altitudes around $2200-2300 \mathrm{~m}$.

At $5500 \mathrm{cal}$. BP a vast coniferous belt was already shaped in the Rila Mountains. The lower part of this vegetation belt was occupied by the communities of Abies alba while Pinus sylvestris and Pinus peuce were confined to areas at higher altitudes.

The dominance of Abies alba in the coniferous belt is documented in the pollen record with $25-35 \%$, particularly for the time interval $6000-2800$ cal. BP, i.e., during the subBoreal (Figure 3). The macrofossil finds of Abies alba (few needles) are occasional, established only in zone MacroOstr-2 (Figure 6) and evidently air-transported upslope. Given that the macrofossil record from the peat-bog Suho Ezero is lacking any plant remains of Abies alba (Bozilova et al., 1990; Bozilova, 1995), compared with $10-15 \%$ presence of Abies pollen, it is logical to assume that the most suitable ecological conditions for the growth of silver fir existed below $1900 \mathrm{~m}$.

Meanwhile, significant changes in the distribution of Pinus sylvestris and Pinus mugo are not observed, whereas a gradual decline in the abundance of Pinus peuce in the approaches to the lakes started after $4500 \mathrm{cal}$. BP, interrupted by a short-term expansion just before 2800 cal. BP. The decline of Pinus peuce coincides with the final establishment of Picea abies $c .4500 \mathrm{cal}$. BP (LPAZ OSTR-2, Figures 3 and 4) followed by its invasion in the coniferous belt after approximately $2700-2800$ cal. BP.

The postglacial establishment of Picea in the study area and in all high Bulgarian mountains (Bozilova, 1996) is rather late compared, for instance, with the situation in the mountains in the northern parts of the Balkan peninsula. For example, Picea was already present in the western and eastern Romanian Carpathians around $11165-10870 \mathrm{cal}$. BP (Farcas et al., 1999; Jalut et al., 2003; Tantau et al., 2003). The early appearance of Picea in the Ljubljana basin, Slovenia, before 14500-14000 cal. BP suggests the existence of refugial areas during the last glacial maximum (Culiberg, 1991). 


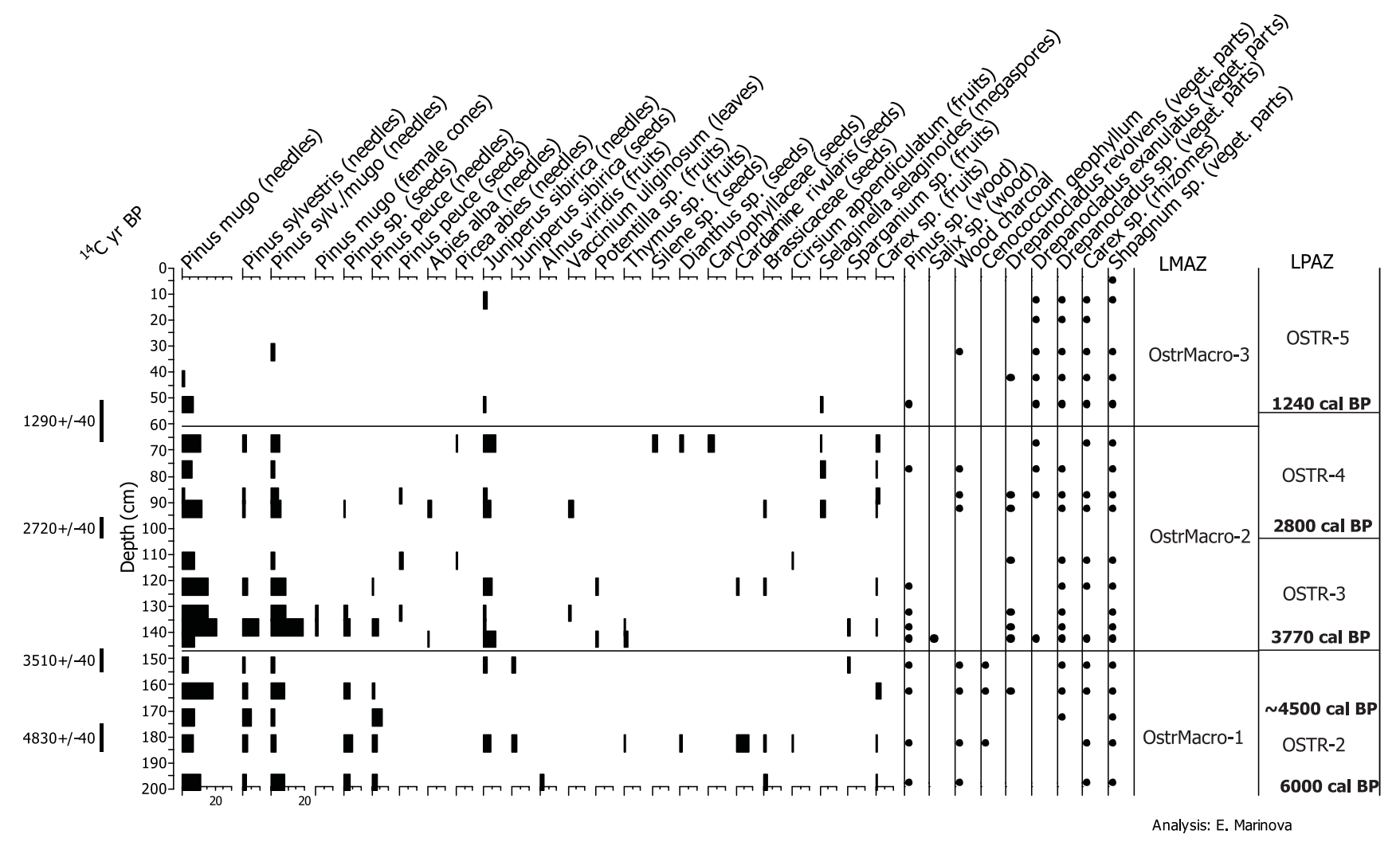

Figure 5 Plant macrofossil diagram from the core Lake Ostrezko-2

The reasons for this late establishment and subsequent expansion of Picea in the central parts of the Balkans are complicated and still debatable. The palynological investigations cited above suggest that the closest refugial areas for Picea were located in the northernmost parts of the Balkan peninsula - Slovenian Alps, Dinaric Mountains and Carpathian Mountains (Lang, 1994; Farcas et al., 1999; Björkman et al., 2003) from where it slowly migrated to the south and southeast. On the other hand, the hypothesis that local residual populations of spruce could also have existed during the

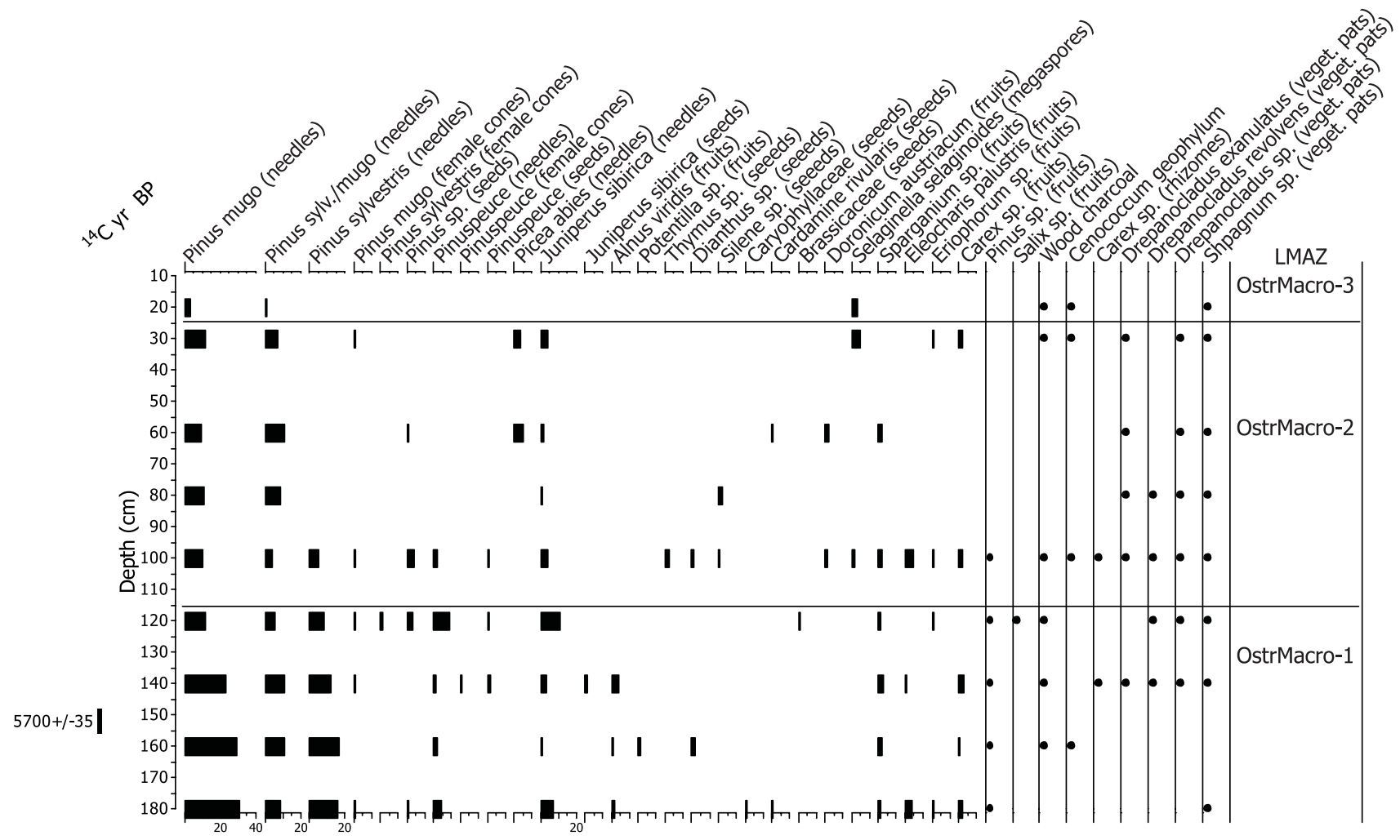

Analysis: E. Marinova

Figure 6 Plant macrofossil diagram from the core Lake Ostrezko-3 
Table 1 Results of radiocarbon measurements

\begin{tabular}{|c|c|c|c|c|}
\hline Lab. no. & Depth $(\mathrm{cm})$ & Age (BP) & Calendar age (cal. BP) & Material dated \\
\hline \multicolumn{5}{|c|}{ Lake Ostrezko-2 } \\
\hline B-6101 & $53-67$ & $1290 \pm 40$ & $1270-1175$ (1238) & peat \\
\hline B-6617 & $95-105$ & $2720 \pm 40$ & $2853-2776(2831)$ & lake mud \\
\hline B-6099 & $146-154$ & $3510 \pm 40$ & $3833-3702$ (3776) & lake mud \\
\hline B-6098 & $175-185$ & $4830 \pm 40$ & $5599-5490(5590)$ & lake mud \\
\hline \multicolumn{5}{|c|}{ Lake Ostrezko-3 } \\
\hline P-174 & $150-156$ & $5700 \pm 35$ & $6620-6406(6455)$ & lake mud \\
\hline
\end{tabular}

Lateglacial in isolated interior montane areas on the Balkan peninsula where moisture was sufficient, also deserves attention (Ravazzi, 2002; Tonkov, 2003).

In the southernmost mountains of Europe, the expansion of the Abies-Picea forest was limited to the mid-late Holocene, owing to increased climatic humidity. However, in forest environments, competition with other trees, notably Abies, was the main factor accounting for reduced migration rates of Picea (de Beaulieu et al., 1994). In the diagrams from Ostrezki Lakes a stepwise decline of Abies pollen begins at c. 3500 cal. BP accompanied by a rise of Picea pollen and the appearance of the first macrofossils (needles) of spruce. The main reason for the expansion of Picea at the sub-Boreal/sub-Atlantic transition in the northern temperate regions is considered a climate change to lower temperatures and higher precipitation, synchronous with an abrupt increase in radiocarbon in the atmosphere c. $850 \mathrm{cal}$. BC as a result of increased solar activity (van Geel et al., 1998). This climate change facilitated the enlargement of the coniferous forests in the high Bulgarian mountains and the formation of numerous peat bogs.

The last spread of Picea forest in the late Holocene is recorded after 1250 cal. BP when it started to descend, replacing Abies at many places in the Rila Mountains in the altitudinal zone 1400-1600 m (Bozilova et al., 2002).

The Holocene distribution pattern of Fagus in the Rila Mountains appears similar to that of Picea. It is worth noting that the climate change in the mid-Holocene has also had a positive effect on the final establishment of Fagus in the Central Rila Mountains c. $5700 \pm 35$ BP (6450 cal. BP) (Figure 4). The enlargement of areas occupied by Fagus at mid altitudes $(1000-1400 \mathrm{~m})$ began at c. 3800 cal. BP. Beech has formed pure stands, or mixed stands with either Abies alba or Carpinus betulus, predominantly on north-facing slopes in the transitional zone between the coniferous and deciduous vegetation belts. When discussing the distribution of Fagus it is important to pay attention to the high capabilities of efficient air-transport of its pollen grains upslope, as has been shown by

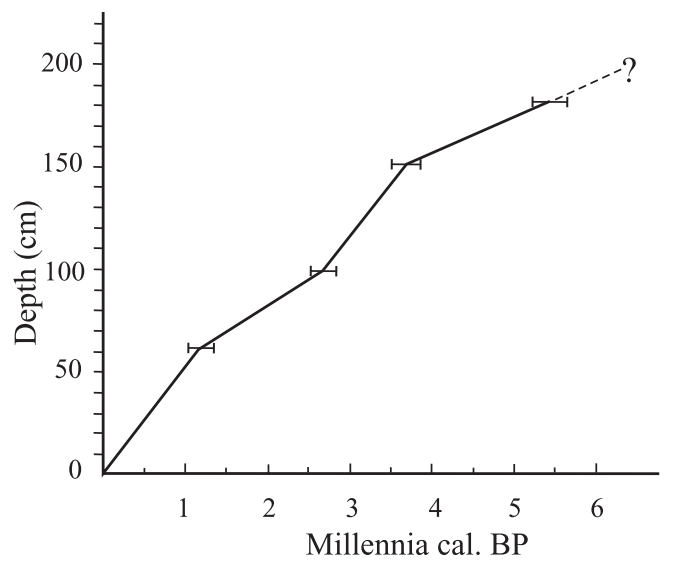

Figure 7 Age as a function of depth for core Lake Ostrezko-2
$4.5-8.4 \%$ abundance in surface moss samples collected at the modern treeline and in the subalpine belt between 2000 and $2200 \mathrm{~m}$ (Tonkov et al., 2000). The present wider distribution of beech forests in the study area at lower altitudes has taken place rather late, around 500-400 cal. BP, coincident with the climate cooling during the 'Little Ice Age' (Bradley and Jones, 1992) (LPAZ OSTR-5, Figure 4).

Evidence for human presence in the subalpine zone at this altitude is observed in both pollen and macrofossil diagrams. The continuous pollen curves of taxa such as Plantago lanceolata, Rumex, Scleranthus, Urtica, considered as indicators of human disturbance in mountainous areas, alongside cereals (Bozilova and Tonkov, 1990), appear at the beginning of LPAZ OSTR-3 at 3770 cal. BP (Figure 3). This complex of pollen types may also include part of the Poaceae, Artemisia and Chenopodiaceae pollen. Numerous wood charcoal fragments are counted just before $3770 \mathrm{cal}$. BP and c. $2800 \mathrm{cal} \mathrm{BP}$. It is logical to presume that some of the forest fires, especially those after $2800 \mathrm{cal}$. BP, were initiated by the local population in order to increase the area of high mountain-pasture land by burning dwarf-pine (Pinus mugo), a management widely practised until c. 50 years ago (Bozilova and Tonkov, 2000). The various macrofossil finds of heliophilous herbs such as Potentilla sp., Thymus sp., Dianthus sp., Silene sp., Doronicum austriacum, etc. (zone MacroOstr-2), accompanied by a decrease of the macrofossil records from conifers (Pinus sylvestris, Pinus peuce), indicate openings in the vegetation and lowering of the treeline.

The poor macrofossil record, comprising only needles of Pinus mugo, Juniperus sibirica and other occasional finds, in the uppermost sections of both cores for the period after 1240 cal. BP (zone MacroOstr-5) reflects the characteristics of the present-day vegetation that dominates around the lakes in the subalpine belt.

\section{Conclusions}

In the context of the intensive ongoing research during the last decade on postglacial sequences in the montane areas of the Balkan peninsula, the following main conclusions could be drawn concerning the palaeovegetation reconstruction in the Central Rila Mountains for the last 6700-6500 years as a result of the multidisciplinary approach combining pollen analysis, plant macrofossil determination and radiocarbon dating.

(1) The formation of a coniferous vegetation belt dominated by Pinus sylvestris, Pinus peuce and Abies alba began after $6700 \mathrm{cal}$. BP. The treeline shaped by Pinus sylvestris and Pinus peuce was higher, up to 2200-2300 m, compared with the present-day. Groups of Pinus mugo and Juniperus sibirica among patches of herb vegetation were distributed in the subalpine zone. 
Table 2 Description of the LPAZ

\begin{tabular}{|c|c|c|}
\hline LPAZ Ostrezko 2/3 Depth (cm) & Age range (cal. yr BP) & Main features of the LPAZ \\
\hline OSTR-1 180-115 & $\sim 6500-6000$ & $\begin{array}{l}\text { Dominance of Pinus diploxylon } 40-45 \% \text {, presence of Abies } 10 \% \text {, Pinus peuce } 4 \% \text { and } \\
\text { deciduous tree pollen (Corylus } 10-25 \% \text {, Tilia, Ulmus, Carpinus); appearance of the } \\
\text { Fagus curve; NAP represented by Poaceae } 5-10 \% \text {, Artemisia, Centaurea, Dianthus, etc. }\end{array}$ \\
\hline OSTR-2 200-145/115-75 & $6000-3770$ & $\begin{array}{l}\text { Increase in Abies up to } 30 \% \text { and Pinus diploxylon } 40-60 \% \text {; decline in deciduous tree } \\
\text { pollen (partucularly Corylus); appearance of the Picea curve }\end{array}$ \\
\hline OSTR-3 145-105/75-55 & $3770-2800$ & $\begin{array}{l}\text { Short maximum for Pinus peuce }(6-10 \%) \text {; decline in Abies, synchronous increase in } \\
\text { Picea; great variety of NAP and appearance of anthropogenic indicators (Rumex, } \\
\text { Plantago lanceolata, Urtica) }\end{array}$ \\
\hline OSTR-4 105-53/55-25 & $2800-1240$ & $\begin{array}{l}\text { Maximum for Picea }(6-10 \%) \text {, high values for Pinus diploxylon } 50-60 \% \text {, strong decline } \\
\text { in Abies (5-8\%); great variety of NAP including taxa of local origin (Sphagnum, } \\
\text { Selaginella, Cyperaceae) }\end{array}$ \\
\hline OSTR-5 53-0/25-0 & $1240-0$ & $\begin{array}{l}\text { Rise in Fagus }(10 \%) \text { and partly for Picea; appearance of Castanea, Juglans; increase in } \\
\text { the anthropogenic indicators (Artemisia, Cichoriaceae, Plantago lanceolata, Rumex, } \\
\text { Secale, Hordeum) }\end{array}$ \\
\hline
\end{tabular}

Table 3 Description of the LMAZ

LMAZ Ostrezko 2/3 Depth (cm) Main features of the LMAZ

OstrMacro-1 200-145/180-115 Needles, seeds and female cones of Pinus mugo, Pinus peuce; needles of Pinus sylvestris; wood of Pinus sp.; fruits of Alnus viridis; seeds, fruits of herbs (Dianthus, Silene, Thymus, etc.); charcoal particles

OstrMacro-2 145-60/115-25 Abundance of needles of Pinus mugo, Pinus sylvestris, Juniperus sibirica; first records of Picea abies and Abies alba (needles); seeds of herbs (Cardamine, Cirsium, Doronicum, etc.); moss remains

OstrMacro-3 60-0/25-0 Poor macrofossil content: sporadic finds of needles of Pinus mugo, Pinus sylvestris, Juniperus sibirica; vegetative parts of mosses (Sphagnum, Drepanocladus)

(2) The mid-Holocene pollen assemblages at low altitudes were dominated by deciduous trees (Quercetum mixtumCorylus phase) that lasted until c. $6000 \mathrm{cal}$. BP.

(3) The wide distribution of Abies alba in the lower part of the coniferous belt was confined to the time window 6000 2800 cal. BP, i.e., during the sub-Boreal, with a maximum at c. 3800 cal. BP.

(4) The establishment of Fagus sylvatica and Picea abies took place at c. 6500 and $4500 \mathrm{cal}$. BP, respectively. Both tree species began gradually to enlarge their areas after $3800-$ 3500 cal. BP. The final expansion of the beech forests at low altitudes took place $c$. 500-400 cal. BP, coincident with the climate cooling during the 'Little Ice Age'.

(5) Traces of human impact are continuously registered in the pollen and plant macrofossil records since $3770 \mathrm{cal}$. BP. In historical times the changes in the vegetation cover at higher altitudes, and the lowering of the treeline, were primarily caused by increasing anthropogenic activities, indicating livestock-grazing and burning of dwarf-pine (Pinus mugo).

\section{Acknowledgements}

We thank Professor E. Bozilova, Associated Professors D. Pavlova and E. Kozuharova, the staffs of the local Forest Farm and the Rila Monastery Nature Park for field assistance.
The authors thank Professor B. Ammann (Institute of Plant Sciences, University of Bern, Switzerland) for funding the series of radiocarbon dates for core Lake Ostrezko-2 performed by Prof. H. H. Loosli, Dr. S. Harrison and Dr. G.J. van Klinken for the radiocarbon date for core Lake Ostrezko-3. The anonymous reviewers and the editor Professor F. Chambers offered useful critical comments to improve the manuscript. The investigation was financially supported by the Sofia University St Kliment Ohridski Research Fund through Project No.101/2004.

\section{References}

Beijerinck, W. 1947: Atlas of seeds and fruits. Wageningen: H.Veeman \& Zonnen.

Bennett, K.D. and Willis, K.J. 1995: The role of ecological factors in controlling vegetation dynamics on long temporal scale. Giornale Botanico Italiano 129, 243-54.

Beug, H.-J. 1961: Leitfaden der Pollenbestimmung fur Mitteleuropa und angrenzende Gebiete. Stuttgart: Fischer.

Björkman, L., Feurdean, A. and Wohlfarth, B. 2003: Late-Glacial and Holocene forest dynamics at Steregoiu in the Gutaiului Mountains, Northwest Romania. Review Palaeobotany \& Palynology 124, 79-111.

Bondev, I. 1991: Vegetation of Bulgaria. Map 1:600000 with explanatory text. Sofia: St. Kliment Ohridski University Press (in Bulgarian with English summary).

Bozilova, E. 1995: The upper forest limit in the Rila Mountains in Postglacial time - palaeoecological evidence from pollen analysis, macrofossil plant remains and ${ }^{14} \mathrm{C}$ dating. In Bozilova, E. and Tonkov, S., editors, Advances in Holocene palaeoecology in Bulgaria. Sofia-Moscow: Pensoft, 1-8.

_ 1996: Bulgaria. Type region BG-e, Vitosha, Rila, Pirin and Rhodopes Mountains. In Berglund, B., Birks, H.J.B., RalskaJasiewiczowa, M. and Wright, H.E., editors, Palaeoecological events during the last 15000 years. Chichester: John Wiley \& Sons, 719-21.

Bozilova, E. and Smit, A. 1979: Palynology of Lake Sucho Ezero in South Rila Mountians (Bulgaria). Phytology 11, 54-67.

Bozilova, E. and Tonkov, S. 1990: The impact of Man on the natural vegetation in Bulgaria from the Neolithic to the Middle Ages. In Bottema, S., Entjes-Nieborg, G. and van Zeist, W., editors, Man's role in the shaping of the Eastern Mediterranean landscape. Rotterdam: Balkema, 327-32.

- 2000: Pollen from Lake Sedmo Rilsko reveals southeast European postglacial vegetation in the highest mountain area of the Balkans. New Phytologist 148, 315-25.

Bozilova, E., Tonkov, S. and Pavlova, D. 1990: Pollen and plant macrofossil analyses of the Lake Suho Ezero in the South Rila 
mountains. Annual of Sofia University, Faculty of Biology 80, 4857.

Bozilova, E., Tonkov, S., Marinova, E. and Jüngner, H. 2002: Pollen and plant macrofossil analyses of Late Holocene sediments from Lake Panichishte in Northwestern Rila Mountains, Bulgaria. Razprave IV. Razreda SAZU XLIII-2, 49-62.

Bradley, R. and Jones, P. 1992: Introduction. In Bradley, R. and Jones, P., editors, Climate since A.D. 1500. London: Routledge, 116 .

Bronk Ramsey, C. 2000: OxCal Program v3.5. Oxford: University of Oxford, Radiocarbon Accelerator Unit.

Cheddadi, R., Yu, G., Guiot, J., Harrison, S.P. and Prentice, I.C. 1997: The climate of Europe 6000 years ago. Climate Dynamics 13, $1-9$.

Culiberg, M. 1991: Late Glacial vegetation in Slovenia. Dela 4. Razreda SAZU (Slovenska Academija Znanosti Umetnosti) 29, 152 .

Davis, B.A.S., Brewer, S., Stevenson, A.C., Guiot, J. and Data Contributors 2003: The temperature of Europe during the Holocene reconstructed from pollen data. Quaternary Science Reviews 22, 1701-16.

de Beaulieu, J.-L., Richard, H., Ruffaldi, P. and Clerc, J. 1994: History of vegetation, climate and human action in the French Alps and the Jura over the last 15000 years. Dissertacione Botanicae 234, 253-75.

Faegri, K. and Iversen, J. 1989: Textbook of pollen analysis. Chichester: John Wiley \& Sons.

Farcas, S., de Beaulieu, J.-L., Reille, M., Coldea, G., Diaconeasa, B., Goeury, C., Goslar, T. and Jull, T. 1999: First ${ }^{14} \mathrm{C}$ datings of Late Glacial and Holocene pollen sequencies from the Roumanian Carpathians. Compte Rendu de l'Academic des Sciences Paris, Sciences de la vie 322, 799-807.

Glovnja, M. 1968: The glacial and periglacial relief in the southern part of Central Rila Mountains. Annual of Sofia University, Faculty of Geology and Geography 61, 37-68.

Grimm, E. 1987: CONISS: a Fortran 77 program for stratigraphically constraint cluster analysis by the method of incremental squares. Computer Geoscience 13, 13-35.

- 1991: TILIA and TILIA*GRAPH. Springfield IL: Illinois State Museum.

Jalut, G., Bodnariuc, A., Bouchette, A., Dedoubat, J.-J., Otto, T. and Fontugne, M. 2003: Holocene vegetation and human impact in the Apuseni Mountains, Central Romania. In Tonkov, S., editor, Aspects of palynology and palaeoecology. Festschrift in honour of Elissaveta Bozilova. Sofia: Pensoft, 137-70.

Katz, N., Katz, S. and Kipiani, M. 1977: Atlas and keys of fruits and seeds occuring in the Quaternary deposits of the USSR. Moscow: Nauka (in Russian).

Lang, G. 1994: Quartare Vegetationsgeschichte Europas. Jena: Gustav Fischer Verlag.

Lang, G. and Tobolski, K. 1985: Late-glacial and holocene environments of a lake at the timberline in the Central Swiss Alps. In Lang, G., editor, Swiss lake, mire and river environments. Vaduz: Cramer, 209-28.
Marinova, E. and Tonkov, S. 2003: Macrofossil records of tree species in the sediments of Lake Panichishte (Northwestern Rila Mts.). In Rossnev, B., editor, Proceedings of scientific papers. Volume 1. Sofia: Forest Research Institute, Bulgarian Academy of Sciences, 266-70.

Moore, P., Webb, J. and Collinson, M. 1991: Pollen analysis. Second edition. Oxford: Blackwell Scientific.

Ravazzi, C. 2002: Late Quaternary history of spruce in southern Europe. Review Palaeobotany \& Palynology 120, 131-77.

Reasoner, M., Becker, A., Bugmann, H., Graumlich, L., Haeberli, W., Messerli, B. and Oldfield, F. 2001: The mountain research initiative and past global changes. PAGES News 9, 4-6.

Schoch, W., Pavlik, B. and Schweingruber, F. 1988: Botanical macroremains. Bern: Paul Haupt.

Schweingruber, F. 1990: Anatomy of European woods. Bern: Paul Haupt.

Struzkova, D. 2002: Cuticular analysis - a method to distinguish the leaves of Pinus sylvestris L. (Scots Pine) from those of Pinus mugo s. str. (Dwarf Mountain-pine). Vegetation History and Archaeobotany 11, 241-46.

Tantau, J., Reille, M., de Beaulieu, J.-L., Farcas, S., Goslar, T. and Paterne, T. 2003: Vegetation history in the Eastern Romanian Carpathians: pollen analysis of two sequences from the Mohoș crater. Vegetation History and Archaeobotany 12, 113-25.

Tishkov, H. 1976: Le climat des regions montagneuses de la Bulgarie - structure et genese. Sofia: Publishing House of Bulgarian Academy of Sciences (in Bulgarian with French summary).

Tobolski, K. 2000: A guide to peat and lake deposits. Vademecum Geobotanicum. Warsaw: Nukowe PWN (in Polish).

Tonkov, S. 2003: Holocene palaeovegetation in the northwestern Pirin Mountains as reconstructed from pollen analysis. Review Palaeobotany \& Palynology 124, 51-61.

Tonkov, S., Atanassova, J., Bozilova, E. and Skog, G. 1998: Pollen analysis of Lake Suho Ezero (Rila Monastery area, Central Rila Mts.). Phytologia Balcanica 4/3, 31-38.

Tonkov, S., Bozilova, E., Pavlova, D. and Kozuharova, E. 2000: Surface pollen moss samples from the valley of the Rilska Reka river, Central Rila Mts. (Southwestern Bulgaria). Annual of Sofia University, Faculty of Biology 91, 63-74.

van Geel, B., van der Plicht, J., Killian, R., Klaver, E.R., Kouwenberg, J.H.M., Renssen, H., Reynaud-Farrera, I. and Waterbolk, H.T. 1998: The sharp rise of C14 ca. 800 cal. BC: possible causes, related climatic teleconnections and the impact of human environments. Radiocarbon 40, 535-50.

Velchev, A. 1995: The Pleistocene glaciations in the Bulgarian mountains. Annual of Sofia University, Faculty of Geology and Geography 87, 53-65 (in Bulgarian with English summary).

Velchev, V. and Tonkov, S. 1986: Vegetation and flora of Southwestern Bulgaria. In Botev, B., editor, Fauna of Southwestern Bulgaria. Sofia: Publishing House of Bulgarian Academy of Sciences, 20-43 (in Bulgarian with English summary). Willis, K.J. 1994: The vegetational history of the Balkans. Quaternary Science Reviews 13, 769-88. 